Published in final edited form as:

Am J Hematol. 2012 January ; 87(1): 78-88. doi:10.1002/ajh.22237.

\title{
Multiple myeloma: 2012 update on diagnosis, risk-stratification, and management
}

\author{
S. Vincent Rajkumar \\ Division of Hematology, Mayo Clinic Rochester, Minnesota
}

\begin{abstract}
Disease overview-Multiple myeloma accounts for $\sim 10 \%$ of all hematologic malignancies.

Diagnosis-The diagnosis requires $10 \%$ or more clonal plasma cells on bone marrow examination or a biopsy proven plasmacytoma plus evidence of end-organ damage felt to be related to the underlying plasma-cell disorder.
\end{abstract}

Risk stratification-Patients with $17 \mathrm{p}$ deletion, $\mathrm{t}(14 ; 16), \mathrm{t}(14 ; 20)$, or high-risk gene expression profiling signature have high-risk myeloma. Patients with $\mathrm{t}(4 ; 14)$ translocation, karyotypic deletion 13, or hypodiploidy are considered to have intermediate-risk disease. All others are considered to have standard-risk myeloma.

Risk-adapted therapy-Standard-risk patients are treated with nonalkylator-based therapy such as lenalidomide plus low-dose dexamethasone ( $\mathrm{Rd})$ followed by autologous stem-cell transplantation (ASCT). An alternative strategy is to continue initial therapy after stem-cell collection, reserving ASCT for first relapse. Intermediate-risk and high-risk patients are treated with a bortezomib-based induction followed by ASCT and then bortezomib-based maintenance. Patients not eligible for ASCT can be treated with Rd for standard risk disease, or with a bortezomib-based regimen if intermediate-risk or high-risk features are present. To reduce toxicity, when using bortezomib, the once-weekly subcutaneous dose is preferred; similarly, when using dexamethasone, the low-dose approach ( $40 \mathrm{mg}$ once a week) is preferred, unless there is a need for rapid disease control.

Management of refractory disease-Patients with indolent relapse can be treated first with two-drug or three-drug combinations. Patients with more aggressive relapse often require therapy with a combination of multiple active agents. The most promising new agents in development are pomalidomide and carfilizomib.

\section{Introduction}

Multiple myeloma accounts for $1 \%$ of all cancers and $\sim 10 \%$ of all hematologic malignancies $[1,2]$. Each year, over 20,000 new cases are diagnosed in the United States [3]. The annual age-adjusted incidence in the United States has remained stable for decades at approximately four per 100,000 [4]. Multiple myeloma is slightly more common in men than in women and is twice as common in African- Americans compared to Caucasians [5]. The median age of patients at the time of diagnosis is about 65 years [6].

\footnotetext{
(C) 2011 Wiley Periodicals, Inc.

*Correspondence to: S. Vincent Rajkumar, Professor of Medicine, Mayo Clinic; Division of Hematology, 200 First Street SW, Rochester, MN 55905, USA. rajkumar.vincent@ mayo.edu.

Conflict of interest: Nothing to report
} 
Unlike other malignancies that metastasize to bone, the osteolytic bone lesions in myeloma exhibit no new bone formation. Bone disease is the main cause of morbidity and can be detected on routine skeletal radiographs, magnetic resonance imaging (MRI), or fluorodeoxyglucose positron emission tomography/computed tomographic scans (PET/ CT) [7]. Other major clinical manifestations are anemia, hypercalcemia, renal failure, and an increased risk of infections. Approximately $1-2 \%$ of patients have extramedullary disease (EMD) at the time of initial diagnosis, while $8 \%$ develop EMD later on in the disease course [8].

Almost all patients with myeloma evolve from an asymptomatic premalignant stage termed monoclonal gammopathy of undetermined significance (MGUS) $[9,10]$. MGUS is present in over $3 \%$ of the population above the age of 50 and progresses to myeloma or related malignancy a rate of $1 \%$ per year [11,12]. In some patients, an intermediate asymptomatic but more advanced premalignant stage referred to as smoldering multiple myeloma (SMM) can be recognized clinically [13]. SMM progressed to myeloma at a rate of $\sim 10 \%$ per year over the first 5 years following diagnosis, $3 \%$ per year over the next 5 years, and $1.5 \%$ per year thereafter.

\section{Diagnosis}

The diagnosis of myeloma requires (1) 10\% or more clonal plasma cells on bone marrow examination or a biopsy proven plasmacytoma and (2) evidence of end-organ damage (hypercalcemia, renal insufficiency, anemia, or bone lesions) that is felt to be related to the underlying plasma cell disorder (Table I) [27]. When multiple myeloma is suspected clinically, patients should be tested for the presence of $\mathrm{M}$ proteins using a combination of tests that should include a serum protein electrophoresis, serum immunofixation, and the serum-free light chain (FLC) assay [28]. Approximately $2 \%$ of patients with multiple myeloma have true nonsecretory disease and have no evidence of an $\mathrm{M}$ protein on any of the above studies [6].

Bone marrow studies at the time of initial diagnosis should include fluorescent in situ hybridization (FISH) designed to detect $\mathrm{t}(11 ; 14), \mathrm{t}(4 ; 14), \mathrm{t}(14 ; 16), \mathrm{t}(6 ; 14), \mathrm{t}(14 ; 20)$, hyperdiploidy, and deletion 17p (see Risk-Stratification below) [29]. Conventional karyotyping to detect hypodiploidy and deletion 13 has value, but if FISH studies are done, additional value in initial risk-stratification is limited. Gene expression profiling, if available, can provide additional prognostic value [30]. Serum CrossLaps to measure carboxy-terminal collagen crosslinks may be useful in assessing bone turnover and to determine adequacy of bisphosphonate therapy [31,32]. Although plain radiographs of the skeleton are typically required to assess the extent of bone disease, PET-CT and MRI scans are more sensitive and are indicated when symptomatic areas show no abnormality on routine radiographs, when there is doubt about the true extent of bone disease on plain radiographs alone, and when solitary plasmacytoma or SMM is suspected [33].

The $\mathrm{M}$ protein is considered to be measurable if it is $\geq 1 \mathrm{~g} / \mathrm{dL}$ in the serum and or $\geq 200 \mathrm{mg} /$ day in the urine. The $\mathrm{M}$ protein level is monitored by serum and urine protein electrophoresis to assess treatment response every month while on therapy, and every 3-4 months when off-therapy. The serum FLC assay is used to monitor patients with myeloma who lack a measurable M protein, provided the FLC ratio is abnormal, and the involved FLC level is $\geq 100 \mathrm{mg} / \mathrm{L}$ [34]. Response to therapy is assessed using the International Myeloma Working Group uniform response criteria [35]. 


\section{Risk-Stratification}

Prognosis in myeloma depends on host factors (age, performance status, and comorbidities), stage, disease aggressiveness, and response to therapy [36]. Staging of myeloma using the Durie-Salmon staging [37] or the International Staging System [38,39] provides prognostic information but is not helpful in making therapeutic choices. A risk stratification model that relies on a number of independent molecular cytogenetic markers to assess disease aggressiveness is useful for both counseling and therapeutic decision-making [40]. At the Mayo Clinic, newly diagnosed myeloma is stratified into standard-, intermediate-, and highrisk disease using the Mayo stratification for myeloma and risk-adapted therapy classification (Table II) [29]. Patients with standard risk myeloma have a median overall survival (OS) of 6-7 years, while those with high risk disease have a median OS of less than 2-3 years despite tandem autologous stem-cell transplantation (ASCT) [1].

\section{RISK-Adapted Therapy}

OS in myeloma has improved significantly in the last decade [41] with the emergence of thalidomide [42], bortezomib [43], and lenalidomide [44,45]. Bortezomib is a proteasome inhibitor [46-48]; the mechanism of action of thalidomide and lenalidomide is unclear, but they are considered immunomodulatory agents [49] and may require cereblon (the putative primary teratogenic target for thalidomide) [50] expression for their antimyeloma activity [51].

The approach to treatment of symptomatic newly diagnosed multiple myeloma is outlined in Fig. 1 and dictated by eligibility for ASCT and risk-stratification [1]. The major regimens used for therapy and the data to support their use are listed in Tables III and IV. There is an ongoing "cure versus control" debate on whether we should treat myeloma with an aggressive multidrug strategy targeting complete response (CR) or a sequential disease control approach that emphasizes quality of life as well as OS $[2,76]$. Based on recent data, high-risk patients require a CR for long-term OS and hence clearly need an aggressive strategy [77]. On the other hand, standard-risk patients have similar OS regardless of whether $\mathrm{CR}$ is achieved or not and therefore have the option of pursuing either an aggressive or a sequential approach.

\section{Options for initial treatment in patients eligible for ASCT}

Typically, patients are treated with approximately two to four cycles of induction therapy before stem-cell harvest. After harvest, patients can either undergo frontline ASCT or resume induction therapy delaying ASCT until first relapse.

\section{Thalidomide-dexamethasone}

In randomized trials [53,54], response rates and time to progression (TTP) are higher with TD compared to dexamethasone alone. However, TD is inferior in terms or activity and toxicity compared with lenalidomide-based regimens and is not recommended as the standard frontline therapy except in countries where lenalidomide is not available for initial therapy and in patients with acute renal failure where it can be used effectively in combination with bortezomib. Patients receiving thalidomide-based regimens require DVT prophylaxis with aspirin, low-molecular weight heparin, or coumadin [78-80].

\section{Lenalidomide-low-dose dexamethasone}

Lenalidomide plus high-dose dexamethasone is active in newly diagnosed myeloma [44,81]. $\mathrm{Rd}$, which combines lenalidomide with a lower dose of dexamethasone (40 mg once weekly), has less toxicity and better OS than lenalidomide plus high-dose dexamethasone 
[55]. Rd may impair collection of peripheral blood stem cells for transplant in some patients when mobilized with granulocyte stimulating factor (G-CSF) alone [82]. Thus, patients over the age of 65 and those who have received more that four cycles of Rd, stem cells must be mobilized with either cyclophosphamide plus GCSF or with plerixafor [83,84]. All patients require antithrombosis prophylaxis with aspirin; low-molecular weight heparin or coumadin is needed in patients at high risk of DVT [78-80].

\section{Bortezomib-containing regimens}

Bortezomib, alone and in combination with dexamethasone has shown activity in newly diagnosed myeloma. Harousseau et al. [70] compared bortezomib plus dexamethasone (VD) versus vincristine, adriamycin, dexamethasone (VAD) as pretransplant induction therapy. Postinduction very good partial response (VGPR) was superior with VD compared to VAD, $38 \%$ versus $15 \%$, respectively. This translated into superior VGPR posttransplant, 54\% versus $37 \%$, respectively. However, progression- free survival (PFS) improvement was modest, 36 months versus 30 months, respectively, and did not reach statistical significance. No OS benefit is apparent so far.

Three-drug regimens containing bortezomib such as bortezomib-cyclophosphamidedexamethasone (VCD), bortezomib-thalidomide-dexamethasone (VTD), and bortezomiblenalidomide- dexamethasone (VRD) are highly active [65]. In randomized trials, VTD has shown better response rates and PFS compared to TD [62] as well as VD [71]. A South-west Oncology Group randomized trial is currently comparing VRd to Rd in the United States. VCD has significant activity in newly diagnosed multiple myeloma [63] and is less expensive than either VTD or VRD. Preliminary studies indicate that VCD is well tolerated and has similar activity compared to VRD, making it an excellent choice when considering a bortezomib-containing regimen for frontline use [66]. There are no data on whether these regimens are superior to Rd in terms of OS and no data comparing the quality of life across the various combinations that can be used in initial therapy. However, bortezomibcontaining regimens appear to overcome the poor prognosis associated with the $t 4 ; 14$ translocation and certain other cytogenetic abnormalities $[62,68,69,85]$.

The major drawback of bortezomib-containing regimens is the risk of neurotoxicity early in the disease course. The neuropathy with bortezomib can occur abruptly and can be significantly painful and debilitating in a subset of patients. Recent studies show that the neurotoxicity of bortezomib can be greatly diminished by administering bortezomib using a once-weekly schedule [59,60] and by administering the drug subcutaneously [86]. Unlike lenalidomide, bortezomib does not appear to have any adverse effect on stem-cell mobilization [87].

\section{Multidrug combinations}

Besides the regimens discussed earlier, another option is multiagent combination chemotherapy, such as VDT-PACE (bortezomib, dexamethasone, thalidomide, cisplatin, doxorubicin, cyclophosphamide, and etoposide) $[68,69]$. VDT-PACE is particularly useful in patients with aggressive disease such as plasma-cell leukemia or multiple extramedullary plasmacytomas. Several other regimens have been tested in newly diagnosed multiple myeloma, but there are no clear data from randomized controlled trials that they have an effect on long-term endpoints compared with the regimens discussed earlier.

\section{Recommendations}

Unfortunately, the various options for treatment discussed earlier have not been compared in adequately powered clinical trials with relevant end-points to determine the best treatment strategy. 
- In low-risk patients, I favor Rd as initial therapy for 4 months, followed by stemcell harvest and ASCT. In patients who are tolerating therapy and responding well, it is equally reasonable to continue Rd after stem-cell collection, reserving ASCT for first relapse. With such a strategy, dexamethasone dose is reduced as much as possible or stopped after 1 year.

- In intermediate-risk patients, I favor VCD as initial therapy for four cycles followed by ASCT and then maintenance with a bortezomib-based regimen for at least 2 years.

- In high-risk patients, I favor VRd as initial therapy for four cycles followed by ASCT and then long-term maintenance with a bortezomib-based regimen.

- In patients presenting with acute renal failure suspected to be secondary to lightchain cast nephropathy, I prefer VTD as initial therapy in conjunction with plasma exchange. Plasma exchange is continued daily until the serum-FLC levels are less than $50 \mathrm{mg} / \mathrm{dL}$ and then repeated as needed till VTD is fully effective.

- In patients presenting with plasma-cell leukemia or multiple extramedullary plasmacytomas, I prefer VDT-PACE as initial therapy followed by ASCT and then maintenance with a bortezomib-based regimen.

- Once-weekly subcutaneous bortezomib is preferred in most patients for initial therapy, unless there is felt to be an urgent need for rapid disease control.

- Dexamethasone $40 \mathrm{mg}$ once a week (low-dose dexamethasone) is preferred in most patients for initial therapy, unless there is felt to be an urgent need for rapid disease control.

\section{Options for initial treatment in patients not eligible for ASCT}

In patients with newly diagnosed multiple myeloma who are considered ineligible for ASCT due to age or other comorbidities, the major options at present are either melphalan- based combination therapies or Rd [1]. With melphalan-based therapy, patients are usually treated for a fixed duration of time (9-18 months) and then observed. With Rd, it is unclear whether treatment should continue until relapse or be stopped after a fixed duration of therapy.

\section{Melphalan, prednisone, thalidomide}

Four randomized studies have shown that melphalan, prednisone, thalidomide MPT improves response rates compared to melphalan plus prednisone (MP) $[57,58,72,74,88]$. Four of these trials have shown a significant prolongation of PFS with MPT [57,58,72,88], and an OS advantage has been observed in the two Intergroupe Francophone Myelome trials and in the trial by Wijermans et al. (Table IV) $[57,58,72,74,88]$. Two meta-analyses of these randomized trials have been conducted, and they show a clear superiority of MPT over MP $[89,90]$. Grades $3-4$ adverse events occur in $~ 55 \%$ of patients treated with MPT compared to $22 \%$ with MP [88]. As with Thal/Dex, there is a significant (20\%) risk of DVT with MPT in the absence of thromboprophylaxis.

\section{Bortezomib, melphalan, prednisone}

In a large phase III trial, improved OS compared to MP [61]. There was also a suggestion that bortezomib can overcome some high-risk cytogenetic features [75]. Neuropathy is a significant risk with VMP therapy; grade 3 neuropathy occurred in $13 \%$ of patients versus $0 \%$ with MP [61]. 


\section{Lenalidomide-low-dose dexamethasone}

$\mathrm{Rd}$ is an attractive option for the treatment of elderly patients with newly diagnosed myeloma because of its excellent tolerability, convenience, and efficacy. The 3-year OS rate with Rd in patients 70 and older who did not receive ASCT is 70\% [91] and is comparable to results with MPT and VMP. An ongoing phase III trial is currently comparing MPT versus $\mathrm{Rd}$ for 18 months versus Rd until progression.

\section{Other regimens}

MP may still have a role in elderly patients who do not have access to Rd in whom therapy with MPT or VMP is not considered safe or feasible [92,93]. The addition of lenalidomide to MP (MPR) does not improve PFS compared to MP alone [94]. An ECOG randomized trial (E1A06) is currently comparing MPR to MPT.

\section{Recommendations}

Unfortunately, the various options for treatment discussed earlier have not been compared in adequately powered clinical trials with relevant end-points to determine the best treatment strategy.

- In standard-risk patients, I favor Rd as initial therapy. Dexamethasone dose is reduced as much as possible after the first $4-6$ months and possibly discontinued after the first year. For frail patients, dexamethasone may be started at $20 \mathrm{mg}$ once a week.

- In intermediate-risk patients, I favor VCD as initial therapy for $\sim 1$ year followed if possible by a lower intensity (one dose every 2 weeks) maintenance schedule of bortezomib for 2 years.

- In high-risk patients, I favor VRd as initial therapy for $\sim 1$ year followed by a lower intensity maintenance schedule of bortezomib.

\section{Role of hematopoietic stem-cell transplantation}

\section{Autologous stem-cell transplantation}

ASCT improves median OS in multiple myeloma by $~ 12$ months [95-98]. However, three randomized trials show that OS is similar whether ASCT is done early (immediately following four cycles of induction therapy) or delayed (at the time of relapse as salvage therapy) [99-101]. Furthermore, in a Spanish randomized trial, patients responding to induction therapy failed to benefit from ASCT trial, suggesting that the greatest benefit from early ASCT may be mainly among the small proportion of patients with disease refractory to induction therapy [102]. Two randomized trials have found benefit with tandem (double) versus single ASCT, with the benefit primarily seen in patients failing to achieve CR or VGPR with the first ASCT $[103,104]$. Two other randomized trials, however, have yet to show significant improvement in OS with double ASCT [105,106].

\section{Allogeneic transplantation}

The role of allogeneic and nonmyeloablative-allogeneic transplantation in myeloma is controversial and remains investigational. The TRM (10-20\%) and high GVHD rates even with nonmyeloablative allogeneic transplantation are unacceptably high [107].

\section{Recommendations}

- $\quad$ ASCT should be considered in all eligible patients. But in standard-risk patients responding well to therapy, ASCT can be delayed until first relapse, provided stem cells are harvested early in the disease course. 
- Tandem ASCT is considered only if patients fail to achieve a VGPR with the first ASCT. With modern induction regimens, such patients are a small minority, and even, in this circumstance, patients can be probably treated with maintenance therapy rather than tandem ASCT.

- At present, allogeneic transplantation as frontline therapy should primarily be considered only in the context of clinical trials in multiple myeloma.

\section{Post-transplant maintenance therapy}

There is confusion about whether post-transplant strategies should be referred to as "consolidation" or "maintenance," but these distinctions are semantic and do not distract from the main questions: should we administer post-transplant therapy? Who should receive such therapy? Thalidomide has shown modest PFS and OS benefit as maintenance therapy in two randomized trials $[108,109]$. More recently, two randomized studies have shown better PFS with lenalidomide as post ASCT maintenance therapy [110,111]. However, patients in the control arm of these trials lacked uniform access to the active drug (thalidomide or lenalidomide) at relapse, and it is not clear whether the PFS improvement will be neutralized, because patients in the control arm can always initiate the same therapy at the time of first relapse. There was also a clear increased risk of second cancers with lenalidomide maintenance in both trials. Furthermore, although one of the two trials is showing some OS benefit with lenalidomide maintenance, the data are preliminary, and the magnitude of that benefit is unclear. We need to await mature OS results from both these studies before routine lenalidomide maintenance can be recommended.

In one study, bortezomib administered every other week post-transplant produced better OS than thalidomide maintenance [112]. Although more studies are needed, bortezomib-based maintenance may be important for intermediate-and high-risk patients.

\section{Recommendations}

- At this point, it is not clear whether all patients should receive maintenance therapy post ASCT with either thalidomide or lenalidomide, but results of the maintenance trials must be discussed with the patient, along with the pros and cons of maintenance versus therapy at first relapse.

- I recommend observation alone for most patients post-transplant except those who fail to achieve VGPR (candidates for lenalidomide maintenance) and those with high-risk disease (candidates for bortezomib-based maintenance).

\section{Treatment of relapsed multiple myeloma}

Almost all patients with multiple myeloma eventually relapse. The remission duration in relapsed myeloma decreases with each regimen [113]. The median PFS and OS in patients with relapsed myeloma refractory to lenalidomide and bortezomib is poor, with median times of 5 and 9 months, respectively [114]. Alkylators, corticosteroids, and thalidomide are all known options for therapy. Other options are discussed below.

\section{Bortezomib and lenalidomide-based regimens}

Approximately one-third of patients with relapsed refractory myeloma respond to bortezomib when used as a single agent [43]. Two large phase III trials have shown superior TTP and OS with lenalidomide ( $25 \mathrm{mg}$ oral days $1-21$ every 28 days) plus dexamethasone compared to placebo plus dexamethasone in relapsed multiple myeloma [115,116]. Bortezomib and the immunomodulatory drugs (thalidomide or lenalidomide) can be combined effectively with each other and with other chemotherapy drugs such as 
cyclophosphamide and melphalan to produce highly active combination regimens. For example, in a study of 85 patients with refractory myeloma treated with VTD, 63\% achieved PR including 22\% near CR [117]. Similarly, VRd has shown significant activity in relapsed, refractory myeloma with a PR rate of $67 \%$, including $24 \%$ near CR or better [118].

\section{Liposomal doxorubicin}

A phase III randomized trial found that median TTP was superior with bortezomib plus pegylated liposomal doxorubicin compared to bortezomib alone, 9.3 months versus 6.5 months, respectively, $P<0.001$ [119]. OS at 15 months was also superior, 76\% compared to $65 \%$, respectively, $P=0.03$. Based on this study, liposomal doxorubicin appears to have modest activity in relapsed myeloma and can be considered as an option for the treatment of relapsed myeloma.

\section{Emerging options}

Pomalidomide has significant activity in relapsed refractory myeloma, even in patients failing lenalidomide [120,121]. Another emerging option is carfilzomib, a novel ketoepoxide tetrapeptide proteasome that has shown single agent activity in relapsed refractory multiple myeloma [122]. The most promising agents being investigated besides pomalidomide and carfilzomib are the histone deacetylase inhibitors (vorinostat and panabinostat) and, the anti CS-1 antibody, elotuzumab.

\section{Recommendations}

- Patients who have cryopreserved stem cells early in the disease course should consider ASCT as salvage therapy at first relapse.

- If relapse occurs more than 6 months after stopping therapy, the initial treatment regimen that successfully controlled the myeloma initially can be reinstituted when possible.

- Patients who have an indolent relapse can often be treated first with lenalidomide, bortezomib, or alkylators plus low-dose corticosteroids. These patients present with asymptomatic increases in serum and urine monoclonal protein levels, progressive anemia, or a few small lytic bone lesions.

- Patients with more aggressive relapse often require therapy with a combination of active agents, for example, VCD, VTD, VRd, or VDT-PACE.

- The duration of therapy has not been well addressed in relapsed myeloma, and, in some regimens, such as those employing bortezomib or alkylators, it may be reasonable to stop therapy once a stable plateau has been reached in order to minimize risks of serious toxicity.

\section{References}

1. Rajkumar SV. Treatment of multiple myeloma. Nat Rev Clin Oncol. 2011; 8:479-491. [PubMed: 21522124]

2. Rajkumar SV, Gahrton G, Bergsagel PL. Approach to the treatment of multiple myeloma: A clash of philosophies. Blood. 2011; 118:3205-3211. [PubMed: 21791430]

3. Jemal A, Siegel R, Xu J, Ward E. Cancer Statistics, 2010. CA Cancer J Clin. 2010; 60:277-300. [PubMed: 20610543]

4. Kyle RA, Therneau TM, Rajkumar SV, Larson DR, Plevak MF, Melton LJ III. Incidence of multiple myeloma in Olmsted County, Minnesota: Trend over 6 decades. Cancer. 2004; 101:26672674. [PubMed: 15481060] 
5. Landgren O, Weiss BM. Patterns of monoclonal gammopathy of undetermined significance and multiple myeloma in various ethnic/racial groups: Support for genetic factors in pathogenesis. Leukemia. 2009; 23:1691-1697. [PubMed: 19587704]

6. Kyle RA, Gertz MA, Witzig TE, et al. Review of 1,027 patients with newly diagnosed multiple myeloma. Mayo Clinic Proc. 2003; 78:21-33.

7. Roodman GD. Pathogenesis of myeloma bone disease. Leukemia. 2009; 23:435-441. [PubMed: 19039321]

8. Short KD, Rajkumar SV, Larson D, et al. Incidence of extramedullary disease in patients with multiple myeloma in the era of novel therapy, and the activity of pomalidomide on extramedullary myeloma. Leuk: Off J Leuk Soc Am Leuk Res Fund, UK. 2011; 25:906-908.

9. Landgren O, Kyle RA, Pfeiffer RM, et al. Monoclonal gammopathy of undetermined significance (MGUS) consistently precedes multiple myeloma: A prospective study. Blood. 2009; 113:54125417. [PubMed: 19179464]

10. Weiss BM, Abadie J, Verma P, Howard RS, Kuehl WM. A monoclonal gammopathy precedes multiple myeloma in most patients. Blood. 2009; 113:5418-5422. [PubMed: 19234139]

11. Kyle RA, Therneau TM, Rajkumar SV, et al. A long-term study of prognosis of monoclonal gammopathy of undetermined significance. N Engl J Med. 2002; 346:564-569. [PubMed: 11856795]

12. Kyle RA, Therneau TM, Rajkumar SV, et al. Prevalence of monoclonal gammopathy of undetermined significance. N Engl J Med. 2006; 354:1362-1369. [PubMed: 16571879]

13. Kyle RA, Remstein ED, Therneau TM, et al. Clinical course and prognosis of smoldering (asymptomatic) multiple myeloma. N Engl J Med. 2007; 356:2582-2590. [PubMed: 17582068]

14. The International Myeloma Working Group. Criteria for the classification of monoclonal gammopathies, multiple myeloma and related disorders: A report of the International Myeloma Working Group. Br J Haematol. 2003; 121:749-757. [PubMed: 12780789]

15. Rajkumar SV, Kyle RA. Multiple myeloma: Diagnosis and treatment [see comment]. Mayo Clinic Proc. 2005; 80:1371-1382.

16. Kyle RA, Therneau TM, Rajkumar SV, et al. Long-term follow-up of IgM monoclonal gammopathy of undetermined significance. Blood. 2003; 102:3759-3764. [PubMed: 12881316]

17. Gobbi PG, Baldini L, Broglia C, et al. Prognostic validation of the international classification of immunoglobulin $\mathrm{M}$ gammopathies: A survival advantage for patients with immunoglobulin $\mathrm{M}$ monoclonal gammopathy of undetermined significance? Clin Cancer Res. 2005; 11:1786-1790. [PubMed: 15756000]

18. Kyle RA, Therneau TM, Rajkumar SV, et al. Long-term follow-up of IgM monoclonal gammopathy of undetermined significance. Semin Oncol. 2003; 30:169-171. [PubMed: 12720130]

19. Baldini L, Goldaniga M, Guffanti A, et al. Immunoglobulin M monoclonal gammopathies of undetermined significance and indolent Waldenstrom's macroglobulinemia recognize the same determinants of evolution into symptomatic lymphoid disorders: Proposal for a common prognostic scoring system. J Clin Oncol. 2005; 23:4662-4668. [PubMed: 16034042]

20. Owen RG, Treon SP, Al-Katib A, et al. Clinicopathological definition of Waldenstrom's macroglobulinemia: Consensus panel recommendations from the Second International Workshop on Waldenstrom's macroglobulinemia. Semin Oncol. 2003; 30:110-115. [PubMed: 12720118]

21. Dispenzieri A, Katzmann JA, Kyle RA, et al. Prevalence and risk of progression of light-chain monoclonal gammopathy of undetermined significance: A retrospective population-based cohort study. Lancet. 2010; 375:1721-1728. [PubMed: 20472173]

22. Dimopoulos MA, Moulopoulos LA, Maniatis A, Alexanian R. Solitary plasma-cytoma of bone and asymptomatic multiple myeloma. Blood. 2000; 96:2037-2044. [PubMed: 10979944]

23. Dimopoulos MA, Kiamouris C, Moulopoulos LA. Solitary plasmacytoma of bone and extramedullary plasmacytoma. Hematol—Oncol Clin N Am. 1999; 13:1249-1257.

24. Rajkumar SV, Dispenzieri A, Kyle RA. Monoclonal gammopathy of undetermined significance, Waldenstrom macroglobulinemia, AL amyloidosis, and related plasma cell disorders: Diagnosis and treatment. Mayo Clinic Proc. 2006; 81:693-703. 
25. Dispenzieri A, Kyle RA, Lacy MQ, et al. POEMS syndrome: Definitions and long-term outcome. Blood. 2003; 101:2496-2506. [PubMed: 12456500]

26. Dispenzieri A. POEMS syndrome. Blood Rev. 2007; 21:285-299. [PubMed: 17850941]

27. Kyle RA, Rajkumar SV. Criteria for diagnosis, staging, risk stratification and response assessment of multiple myeloma. Leukemia. 2009; 23:3-9. [PubMed: 18971951]

28. Katzmann JA, Dispenzieri A, Kyle R, et al. Elimination of the need for urine studies in the screening algorithm for monoclonal gammopathies by using serum immunofixation and free light chain assays. Mayo Clin Proc. 2006; 81:1575-1578. [PubMed: 17165636]

29. Kumar SK, Mikhael JR, Buadi FK, et al. Management of newly diagnosed symptomatic multiple myeloma: Updated Mayo Stratification of Myeloma and Risk-Adapted Therapy (mSMART) Consensus Guidelines. Mayo Clinic Proc. 2009; 84:1095-1110.

30. Zhou Y, Barlogie B, Shaughnessy JD Jr. The molecular characterization and clinical management of multiple myeloma in the post-genome era. Leukemia. 2009; 23:1941-1956. [PubMed: 19657360]

31. Dizdar O, Barista I, Kalyoncu U, et al. Biochemical markers of bone turnover in diagnosis of myeloma bone disease. Am J Hematol. 2007; 82:185-191. [PubMed: 17022050]

32. Silvestris F, Lombardi L, De Matteo M, Bruno A, Dammacco F. Myeloma bone disease: Pathogenetic mechanisms and clinical assessment. Leuk Res. 2007; 31:129-138. [PubMed: 16764925]

33. Dimopoulos M, Terpos E, Comenzo RL, et al. International myeloma working group consensus statement and guidelines regarding the current role of imaging techniques in the diagnosis and monitoring of multiple myeloma. Leukemia. 2009; 23:1545-1556. [PubMed: 19421229]

34. Dispenzieri A, Kyle R, Merlini G, et al. International Myeloma Working Group Guidelines for serum-free light chain analysis in multiple myeloma and related disorders. Leukemia. 2009; 23:215-224. [PubMed: 19020545]

35. Durie BGM, Harousseau J-L, Miguel JS, et al. International uniform response criteria for multiple myeloma. Leukemia. 2006; 20:1467-1473. [PubMed: 16855634]

36. Russell SJ, Rajkumar SV. Multiple myeloma and the road to personalised medicine. Lancet Oncol. 2011; 12:617-619. [PubMed: 21664869]

37. Durie BG, Salmon SE. A clinical staging system for multiple myeloma. Correlation of measured myeloma cell mass with presenting clinical features, response to treatment, and survival. Cancer. 1975; 36:842-854. [PubMed: 1182674]

38. Greipp PR, San Miguel JF, Durie BG, et al. International staging system for multiple myeloma. J Clin Oncol. 2005; 23:3412-3420. [PubMed: 15809451]

39. Hari PN, Zhang MJ, Roy V, et al. Is the international staging system superior to the Durie-Salmon staging system? A comparison in multiple myeloma patients undergoing autologous transplant. Leukemia. 2009; 23:1528-1534. [PubMed: 19322205]

40. Fonseca R, Bergsagel PL, Drach J, et al. International Myeloma Working Group molecular classification of multiple myeloma: Spotlight review. Leukemia. 2009; 23:2210-2221. [PubMed: 19798094]

41. Kumar SK, Rajkumar SV, Dispenzieri A, et al. Improved survival in multiple myeloma and the impact of novel therapies. Blood. 2008; 111:2516-2520. [PubMed: 17975015]

42. Singhal S, Mehta J, Desikan R, et al. Antitumor activity of thalidomide in refractory multiple myeloma [see comments]. N Engl J Med. 1999; 341:1565-1571. [PubMed: 10564685]

43. Richardson PG, Sonneveld P, Schuster MW, et al. Bortezomib or high-dose dexamethasone for relapsed multiple myeloma [see comment]. N Engl J Med. 2005; 352:2487-2498. [PubMed: 15958804]

44. Rajkumar SV, Hayman SR, Lacy MQ, et al. Combination therapy with lenalidomide plus dexamethasone (Rev/Dex) for newly diagnosed myeloma. Blood. 2005; 106:4050-4053. [PubMed: 16118317]

45. Richardson PG, Blood E, Mitsiades CS, et al. A randomized phase 2 study of lenalidomide therapy for patients with relapsed or relapsed and refractory multiple myeloma. Blood. 2006; 108:34583464. [PubMed: 16840727] 
46. Rajkumar SV, Richardson PG, Hideshima T, Anderson KC. Proteasome inhibition as a novel therapeutic target in human cancer. J Clin Oncol. 2004; 23:630-639. [PubMed: 15659509]

47. Kumar S, Rajkumar SV. Many facets of bortezomib resistance/susceptibility. Blood. 2008; 112:2177-2178. [PubMed: 18779399]

48. Gutman D, Morales AA, Boise LH. Acquisition of a multidrug-resistant phenotype with a proteasome inhibitor in multiple myeloma. Leukemia. 2009; 23:2181-2183. [PubMed: 19516276]

49. Quach H, Ritchie D, Stewart AK, et al. Mechanism of action of immunomodulatory drugs (IMiDS) in multiple myeloma. Leukemia. 2010; 24:22-32. [PubMed: 19907437]

50. Ito T, Ando H, Suzuki T, et al. Identification of a primary target of thalidomide teratogenicity. Science. 2010; 327:1345-1350. [PubMed: 20223979]

51. Zhu YX, Braggio E, Shi CX, et al. Cereblon expression is required for the anti-myeloma activity of lenalidomide and pomalidomide. Blood. 2011; 118:4771-4779. [PubMed: 21860026]

52. Kyle RA, Rajkumar SV. Multiple myeloma. N Engl J Med. 2004; 351:1860-1873. [PubMed: 15509819]

53. Rajkumar SV, Blood E, Vesole DH, Fonseca R, Greipp PR. Phase III clinical trial of thalidomide plus dexamethasone compared with dexamethasone alone in newly diagnosed multiple myeloma: A Clinical Trial Coordinated by the Eastern Cooperative Oncology Group. J Clin Oncol. 2006; 24:431-436. [PubMed: 16365178]

54. Rajkumar SV, Rosiñol L, Hussein M, et al. A multicenter, randomized, double- blind, placebocontrolled study of thalidomide plus dexamethasone versus dexamethasone as initial therapy for newly diagnosed multiple myeloma. J Clin Oncol. 2008; 26:2171-2177. [PubMed: 18362366]

55. Rajkumar SV, Jacobus S, Callander NS, et al. Lenalidomide plus high-dose dexamethasone versus lenalidomide plus low-dose dexamethasone as initial therapy for newly diagnosed multiple myeloma: An open-label randomised controlled trial. Lancet Oncol. 2010; 11:29-37. [PubMed: 19853510]

56. Harousseau J, Attal M, Leleu X, et al. Bortezomib plus dexamethasone as induction treatment prior to autologous stem cell transplantation in patients with newly diagnosed multiple myeloma: Results of an IFM phase II study. Haematologica. 2006; 91:1498-1505. [PubMed: 17043025]

57. Facon T, Mary JY, Hulin C, et al. Melphalan and prednisone plus thalidomide versus melphalan and prednisone alone or reduced-intensity autologous stem cell transplantation in elderly patients with multiple myeloma (IFM 99-06): A randomised trial. Lancet. 2007; 370:1209-1218. [PubMed: 17920916]

58. Hulin C, Facon T, Rodon P, et al. Efficacy of melphalan and prednisone plus thalidomide in patients older than 75 years with newly diagnosed multiple myeloma: IFM 01/01 Trial. J Clin Oncol. 2009; 27:3664-3670. [PubMed: 19451428]

59. Mateos MV, Oriol A, Martinez-Lopez J. Bortezomib/melphalan/prednisone (VMP) versus bortezomib/thalidomide/prednisone (VTP) as induction therapy followed by maintenance treatment with bortezomib/thalidomide (VT) versus bortezomib/prednisone (VP): A randomised trial in elderly untreated patients with multiple myeloma older than 65 years. Lancet Oncol. 2010; 11:934-941. [PubMed: 20739218]

60. Palumbo A, Bringhen S, Rossi D, et al. Bortezomib-melphalan-prednisone-thalidomide followed by maintenance with bortezomib-thalidomide compared with bortezomib-melphalan-prednisone for initial treatment of multiple myeloma: A randomized controlled trial. J Clin Oncol. 2010; 28:5101-5109. [PubMed: 20940200]

61. San Miguel JF, Schlag R, Khuageva NK, et al. Bortezomib plus melphalan and prednisone for initial treatment of multiple myeloma. N Engl J Med. 2008; 359:906-917. [PubMed: 18753647]

62. Cavo M, Tacchetti P, Patriarca F, et al. Bortezomib with thalidomide plus dexamethasone compared with thalidomide plus dexamethasone as induction therapy before, and consolidation therapy after, double autologous stemcell transplantation in newly diagnosed multiple myeloma: A randomised phase 3 study. Lancet. 2010; 376:2075-2085. [PubMed: 21146205]

63. Reeder CB, Reece DE, Kukreti V, et al. Cyclophosphamide, bortezomib and dexamethasone induction for newly diagnosed multiple myeloma: High response rates in a phase II clinical trial. Leukemia. 2009; 23:1337-1341. [PubMed: 19225538] 
64. Kumar S, Flinn IW, Hari PN, et al. Novel three- and four-drug combinations of bortezomib, dexamethasone, cyclophosphamide, and lenalidomide, for newly diagnosed multiple myeloma: Encouraging results from the multi-center, randomized, phase 2 EVOLUTION Study. ASH Annu Meet Abstr. 2009; 114:127.

65. Richardson PG, Weller E, Lonial S, et al. Lenalidomide, bortezomib, and dexamethasone combination therapy in patients with newly diagnosed multiple myeloma. Blood. 2010; 116:679_ 686. [PubMed: 20385792]

66. Kumar S, Flinn IW, Richardson PG, et al. Novel three- and four-drug combination regimens of bortezomib, dexamethasone, cyclophosphamide, and lenalidomide, for previously untreated multiple myeloma: Results From the Multi-Center, Randomized, Phase 2 EVOLUTION Study. ASH Annu Meet Abstr. 2010; 116:621.

67. Kumar SK, Flinn I, Noga SJ, et al. Bortezomib, dexamethasone, cyclophosphamide and lenalidomide combination for newly diagnosed multiple myeloma: Phase 1 results from the multicenter EVOLUTION study. Leukemia. 2010; 24:1350-1356. [PubMed: 20508619]

68. Barlogie B, Anaissie E, van Rhee F, et al. Incorporating bortezomib into upfront treatment for multiple myeloma: Early results of total therapy 3. Br J Haematol. 2007; 138:176-185. [PubMed: 17593024]

69. van Rhee F, Szymonifka J, Anaissie E, et al. Total therapy 3 for multiple myeloma: Prognostic implications of cumulative dosing and premature discontinuation of VTD maintenance components, bortezomib, thalidomide and dexamethasone, relevant to all phases of therapy. Blood. 2010; 116:1220-1227. [PubMed: 20501894]

70. Harousseau JL, Attal M, Avet-Loiseau H, et al. Bortezomib plus dexamethasone is superior to vincristine plus doxorubicin plus dexamethasone as induction treatment prior to autologous stemcell transplantation in newly diagnosed multiple myeloma: Results of the IFM 2005-01 Phase III Trial. J Clin Oncol. 2010; 28:4621-4629. [PubMed: 20823406]

71. Moreau P, Facon T, Attal M, et al. Comparison of reduced-dose bortezomib plus thalidomide plus dexamethasone (vTD) to bortezomib plus dexamethasone (VD) as induction treatment prior to ASCT in de novo multiple myeloma (MM): Results of IFM2007-02 study. J Clin Oncol. 2010; 28(Suppl):15s. (abstr 8014).

72. Wijermans P, Schaafsma M, Termorshuizen F, et al. Phase III study of the value of thalidomide added to melphalan plus prednisone in elderly patients with newly diagnosed multiple myeloma: The HOVON 49 Study. J Clin Oncol. 2010; 28:3160-3166. [PubMed: 20516439]

73. Palumbo A, Bringhen S, Liberati AM, et al. Oral melphalan, prednisone, and thalidomide in elderly patients with multiple myeloma: Updated results of a randomized controlled trial. Blood. 2008; 112:3107-3114. [PubMed: 18505783]

74. Waage A, Gimsing P, Fayers P, et al. Melphalan and prednisone plus thalidomide or placebo in elderly patients with multiple myeloma. Blood. 2010; 116:1405-1412. [PubMed: 20448107]

75. Mateos M-V, Richardson PG, Schlag R, et al. Bortezomib plus melphalan and prednisone compared with melphalan and prednisone in previously untreated multiple myeloma: Updated Follow-Up and Impact of Subsequent Therapy in the Phase III VISTA Trial. J Clin Oncol. 2010; 28:2259-2266. [PubMed: 20368561]

76. Rajkumar SV. Treatment of myeloma: Cure vs control. Mayo Clinic Proc. 2008; 83:1142-1145.

77. Haessler J, Shaughnessy JD Jr, Zhan F, et al. Benefit of complete response in multiple myeloma limited to high-risk subgroup identified by gene expression profiling. Clin Cancer Res. 2007; 13:7073-7079. [PubMed: 18056185]

78. Palumbo A, Cavo M, Bringhen S, et al. Aspirin, warfarin, or enoxaparin thrombo-prophylaxis in patients with multiple myeloma treated with thalidomide: A phase III, open-label, randomized trial. J Clin Oncol. 2011; 29:986-993. [PubMed: 21282540]

79. Larocca A, Cavallo F, Bringhen S, et al. Aspirin or enoxaparin thrombo-prophylaxis for newlydiagnosed multiple myeloma patients treated with lenalidomide. Blood. 2011 blood-2011-03-344333; published ahead of print August 11, 2011.

80. Palumbo A, Rajkumar SV, Dimopoulos MA, et al. Prevention of thalidomide-and lenalidomideassociated thrombosis in myeloma. Leuk: Off J Leuk Soc Am Leuk Res Fund, UK. 2008; 22:414423. 
81. Zonder JA, Crowley J, Hussein MA, et al. Lenalidomide and high-dose dexamethasone compared with dexamethasone as initial therapy for multiple myeloma: A randomized Southwest Oncology Group trial (S0232). Blood. 2010; 116:5838-5841. [PubMed: 20876454]

82. Kumar S, Dispenzieri A, Lacy MQ, et al. Impact of lenalidomide therapy on stem cell mobilization and engraftment post-peripheral blood stem cell transplantation in patients with newly diagnosed myeloma. Leukemia. 2007; 21:2035-2042. [PubMed: 17581613]

83. Kumar S, Giralt S, Stadtmauer EA, et al. Mobilization in myeloma revisited: IMWG consensus perspectives on stem cell collection following initial therapy with thalidomide-, lenalidomide-, or bortezomib-containing regimens. Blood. 2009; 114:1729-1735. [PubMed: 19561323]

84. Giralt S, Stadtmauer EA, Harousseau JL, et al. International myeloma working group (IMWG) consensus statement and guidelines regarding the current status of stem cell collection and highdose therapy for multiple myeloma and the role of plerixafor (AMD 3100). Leukemia. 2009; 23:1904-1912. [PubMed: 19554029]

85. Nair B, van Rhee F, Shaughnessy JD Jr, et al. Superior results of total therapy 3 (2003-33) in gene expression profiling-defined low-risk multiple myeloma confirmed in subsequent trial 2006-66 with VRD maintenance. Blood. 2010; 115:4168-4173. [PubMed: 20124509]

86. Moreau P, Pylypenko H, Grosicki S, et al. Subcutaneous versus intravenous administration of bortezomib in patients with relapsed multiple myeloma: A randomised, phase 3, non-inferiority study. Lancet Oncol. 2011; 12:431-440. [PubMed: 21507715]

87. Moreau P, Hulin C, Marit G, et al. Stem cell collection in patients with de novo multiple myeloma treated with the combination of bortezomib and dexamethasone before autologous stem cell transplantation according to IFM 2005-01 trial. Leukemia. 2010; 24:1233-1235. [PubMed: 20428201]

88. Palumbo A, Bringhen S, Caravita T, et al. Oral melphalan and prednisone chemotherapy plus thalidomide compared with melphalan and prednisone alone in elderly patients with multiple myeloma: Randomised controlled trial. Lancet. 2006; 367:825-831. [PubMed: 16530576]

89. Kapoor P, Rajkumar SV, Dispenzieri A, et al. Melphalan and prednisone versus melphalan, prednisone and thalidomide for elderly and/or transplant ineligible patients with multiple myeloma: A meta-analysis. Leuk: Off J Leuk Soc Am Leuk Res Fund UK. 2011; 25:689-696.

90. Fayers PM, Palumbo A, Hulin C, et al. Thalidomide for previously untreated elderly patients with multiple myeloma: Meta-analysis of 1685 individual patient data from 6 randomized clinical trials. Blood. 2011; 118:1239-1247. [PubMed: 21670471]

91. Jacobus S, Callander N, Siegel D, et al. Outcome of elderly patients 70 years and older with newly diagnosed myeloma in the ECOG randomized trial of lenalidomide/high-dose dexamethasone (RD) versus lenalidomide/ low-dose dexamethasone (Rd). Haematologica. 2010; 95(Suppl 2):149. (abstr 0370).

92. Kyle RA, Rajkumar SV. Multiple myeloma. Blood. 2008; 111:2962-2972. [PubMed: 18332230]

93. Myeloma Trialists' Collaborative Group. Combination chemotherapy versus melphalan plus prednisone as treatment for multiple myeloma: An overview of 6,633 patients from 27 randomized trials. J Clin Oncol. 1998; 16:3832-3842. [PubMed: 9850028]

94. Palumbo A, Dimopoulos MA, Delforge M, et al. A Phase III study to determine the efficacy and safety of lenalidomide in combination with melphalan and prednisone (MPR) in elderly patients with newly diagnosed multiple myeloma. ASH Annu Meet Abstr. 2009; 114:613.

95. Attal M, Harousseau JL, Stoppa AM, et al. A prospective, randomized trial of autologous bone marrow transplantation and chemotherapy in multiple myeloma. Intergroupe Francais du Myelome. N Engl J Med. 1996; 335:91-97. [PubMed: 8649495]

96. Child JA, Morgan GJ, Davies FE, et al. High-dose chemotherapy with hematopoietic stem-cell rescue for multiple myeloma. N Engl J Med. 2003; 348:1875-1883. [PubMed: 12736280]

97. Blade J, Vesole DH, Gertz M. Transplantation for multiple myeloma: Who, when, how often? Blood. 2003; 102:3469-3477. [PubMed: 12893762]

98. Kumar A, Loughran T, Alsina M, Durie BG, Djulbegovic B. Management of multiple myeloma: A systematic review and critical appraisal of published studies. Lancet Oncol. 2003; 4:293-304. [PubMed: 12732167] 
99. Fermand JP, Ravaud P, Chevret S, et al. High-dose therapy and autologous peripheral blood stem cell transplantation in multiple myeloma: Up-front or rescue treatment? Results of a multicenter sequential randomized clinical trial. Blood. 1998; 92:3131-3136. [PubMed: 9787148]

100. Facon T, Mary JY, Harousseau JL, et al. Front-line or rescue autologous bone marrow transplantation (ABMT) following a first course of high dose melphalan (HDM) in multiple myeloma (MM). Preliminary results of a prospective randomized trial (CIAM) protocol. Blood. 1996; 88(Suppl 1):685a.

101. Barlogie B, Kyle R, Anderson K, et al. Comparable survival in multiple myeloma (MM) with high dose therapy (HDT) employing MEL $140 \mathrm{mg} / \mathrm{m} 21$ TBI 12 Gy autotransplants versus standard dose therapy with VBMCP and no benefit from interferon (IFN) maintenance: Results of Intergroup Trial S9321. Blood. 2003; 102:42a.

102. Blade J, Sureda A, Ribera JM, et al. High-dose therapy autotransplantation/ intensification versus continued conventional chemotherapy in multiple myeloma patients responding to initial chemotherapy. Definitive results from PETHEMA after a median follow-up of 66 months. Blood. 2003; 102:42a.

103. Attal M, Harousseau JL, Facon T, et al. Double autologous transplantation improves survival of multiple myeloma patients: Final analysis of a prospective randomized study of the "Intergroupe Francophone du Myelome" (IFM 94). Blood. 2002; 100:5a.

104. Cavo M, Cellini C, Zamagni E, et al. Superiority of double over single autologous stem cell transplantation as first-line therapy for multiple myeloma. Blood. 2004; 104:155a. (A536).

105. Fermand JP, Alberti C, Marolleau JP. Single versus tandem high dose therapy (HDT) supported with autologous blood stem cell (ABSC) transplantation using unselected or CD34-enriched ABSC: Results of a two by two designed randomized trial in 230 young patients with multiple myeloma (MM). Hematol J. 2003; 4(Suppl 1):S59.

106. Goldschmidt H. Single vs. tandem autolgous transplantation in multiple myeloma: The GMMG experience. Hematol J. 2003; 4(Suppl 1):S61.

107. Stewart AK. Reduced-intensity allogeneic transplantation for myeloma: Reality bites. Blood. 2009; 113:3135-3136. [PubMed: 19342498]

108. Attal M, Harousseau J-L, Leyvraz S, et al. Maintenance therapy with thalidomide improves survival in patients with multiple myeloma. Blood. 2006; 108:3289-3294. [PubMed: 16873668]

109. Spencer A, Prince HM, Roberts AW, et al. Consolidation therapy with low-dose thalidomide and prednisolone prolongs the survival of multiple myeloma patients undergoing a single autologous stem-cell transplantation procedure. J Clin Oncol. 2009; 27:1788-1793. [PubMed: 19273705]

110. Attal M, Cristini C, Marit G, et al. Lenalidomide maintenance after transplantation for myeloma. J Clin Oncol. 2010; 28(Suppl):15s. (abstr 8018).

111. McCarthy PL, Owzar K, Anderson KC, et al. Phase III intergroup study of lenalidomide versus placebo maintenance therapy following single autologous stem cell transplant (ASCT) for multiple myeloma (MM): CALGB 100104. J Clin Oncol. 2010; 28(Suppl):15s. (abstr 8017).

112. Sonneveld P, Schmidt-Wolf I, van der Holt B, et al. HOVON-65/GMMG-HD4 randomized phase III trial comparing bortezomib, doxorubicin, dexamethasone (PAD) vs VAD followed by highdose melphalan (HDM) and maintenance with bortezomib or thalidomide in patients with newly diagnosed multiple myeloma (MM). ASH Annu Meet Abstr. 2010; 116:40.

113. Kumar SK, Therneau TM, Gertz MA, et al. Clinical course of patients with relapsed multiple myeloma. Mayo Clinic Proc. 2004; 79:867-874.

114. Kumar S, Blade J, Crowley J, et al. Outcome of patients with myeloma relapsing after IMiD and bortezomib therapy: A multicenter study from the International Myeloma Foundation Working Group. Haematologica. 2010; 95(Suppl 2):151. (abstr 0376).

115. Dimopoulos M, Spencer A, Attal M, et al. Lenalidomide plus dexamethasone for relapsed or refractory multiple myeloma. N Engl J Med. 2007; 357:2123-2132. [PubMed: 18032762]

116. Weber DM, Chen C, Niesvizky R, et al. Lenalidomide plus dexamethasone for relapsed multiple myeloma in North America. N Engl J Med. 2007; 357:2133-2142. [PubMed: 18032763]

117. Pineda-Roman M, Zangari M, van Rhee F, et al. VTD combination therapy with bortezomibthalidomide-dexamethasone is highly effective in advanced and refractory multiple myeloma. Leukemia. 2008; 22:1419-1427. [PubMed: 18432260] 
118. Richardson P, Jagannath S, Jakubowiak A, et al. Lenalidomide, bortezomib, and dexamethasone in patients with relapsed or relapsed/refractory multiple myeloma (MM): Encouraging response rates and tolerability with correlation of outcome and adverse cytogenetics in a phase II study. Blood (ASH Annual Meeting Abstracts). 2008; 112:1742.

119. Orlowski RZ, Nagler A, Sonneveld P, et al. Randomized phase III study of pegylated liposomal doxorubicin plus bortezomib compared with bortezomib alone in relapsed or refractory multiple myeloma: Combination therapy improves time to progression. J Clin Oncol. 2007; 25:38923901. [PubMed: 17679727]

120. Lacy MQ, Hayman SR, Gertz MA, et al. Pomalidomide (CC4047) plus low-dose dexamethasone as therapy for relapsed multiple myeloma. J Clin Oncol. 2009; 27:5008-5014. [PubMed: 19720894]

121. Lacy MQ, Hayman SR, Gertz MA, et al. Pomalidomide (CC4047) plus low dose dexamethasone (Pom/dex) is active and well tolerated in lenalidomide refractory multiple myeloma (MM). Leuk: Off J Leuk Soc Am Leuk Res Fund UK. 2010; 24:1934-1939.

122. Demo SD, Kirk CJ, Aujay MA, et al. Antitumor activity of PR-171, a novel irreversible inhibitor of the proteasome. Cancer Res. 2007; 67:6383-6391. [PubMed: 17616698] 


\section{A Newly Diagnosed Myeloma Eligible for Transplantation}
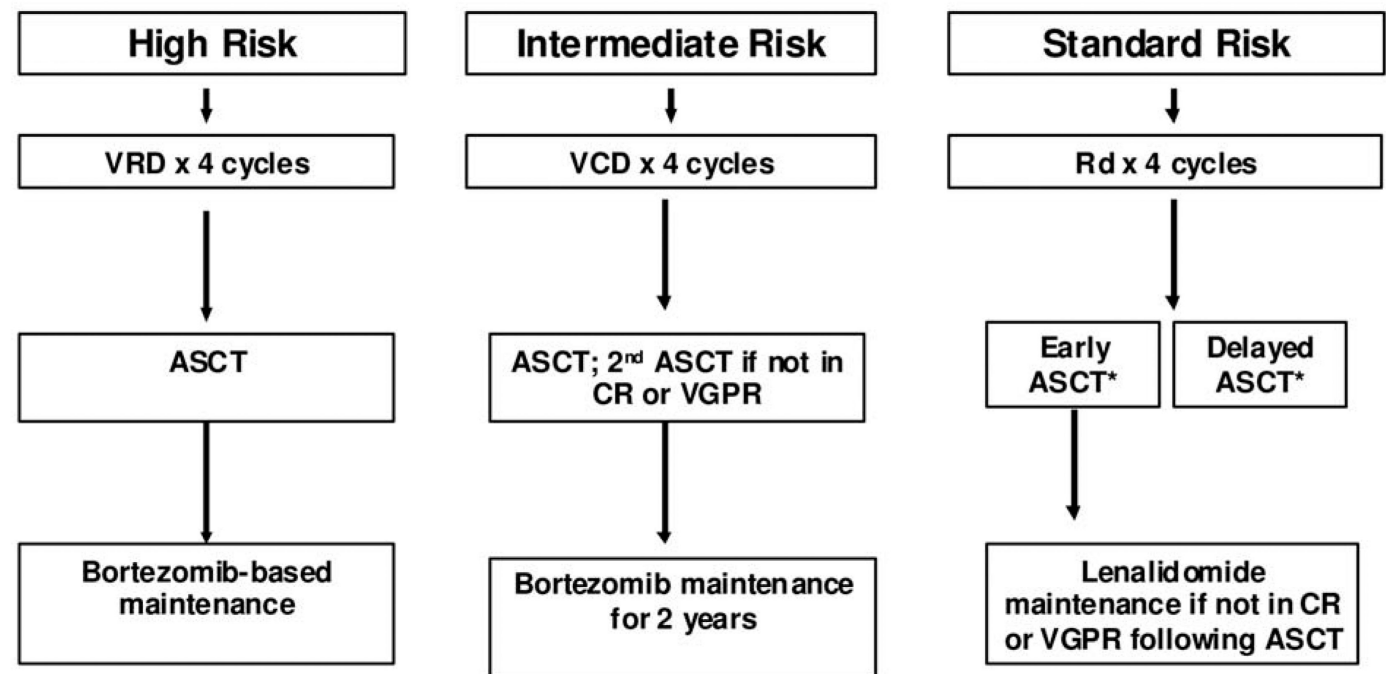

${ }^{*}$ For patients who choose delayed ASCT, dexamethasone usually discontinued after 12 months, and continued long-term lenalidomide is an option for patients who are tolerating treatment well.

\section{B Newly Diagnosed Myeloma Not Eligible for Transplantation}
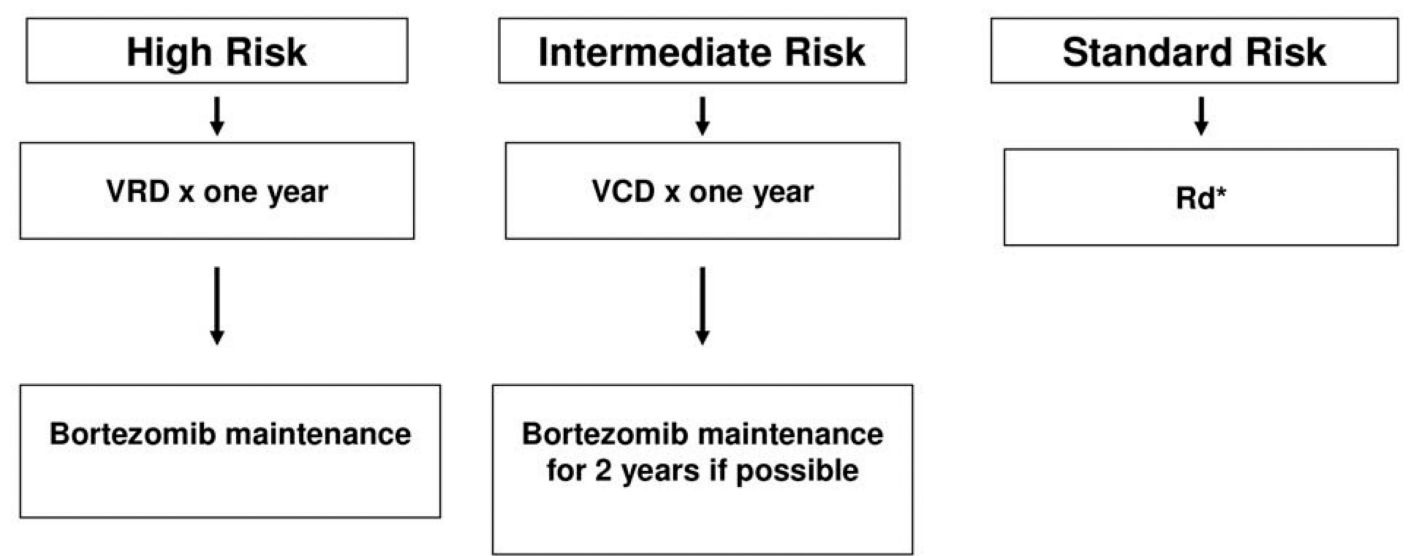

*Dexamethasone usually discontinued after 12 months; continued long-term lenalidomide is an option for patients who are tolerating treatment well.

Figure 1.

Approach to the treatment of newly diagnosed myeloma in patients eligible for transplantation (A) and not eligible for transplantation (B). Abbreviations: ASCT, autologous stem-cell transplantation; CR, complete response; Dex, dexamethasone; Rd, lenalidomide plus low-dose dexamethasone; VCD, bortezomib, cyclophosphamide, dexamethasone; VGPR, very good partial response; VRD, bortezomib, lenalidomide, dexamethasone. Modified from: Rajkumar SV. Treatment of Multiple Myeloma. Nat Rev Clin Oncol 2011;8:479-491. 


\section{TABLE I}

\section{Diagnostic Criteria for Plasma-Cell Disorders}

\begin{tabular}{l} 
Disorder \\
\hline $\begin{array}{l}\text { Monoclonal gammopathy of undetermined } \\
\text { significance (MGUS) }\end{array}$ \\
Smoldering multiple myeloma (also referred \\
to as asymptomatic multiple myeloma)
\end{tabular}

Disease definition

References

All three criteria must be met:

Serum monoclonal protein $<3 \mathrm{~g} / \mathrm{dL}$

Clonal bone marrow plasma cells $<10 \%$, and

Absence of end-organ damage such as hypercalcemia, renal insufficiency, anemia, and bone lesions (CRAB) that can be attributed to the plasma cellproliferative disorder; or in the case of IgM MGUS no evidence of anemia, constitutional symptoms, hyperviscosity, lymphadenopathy, or hepatosplenomegaly that can be attributed to the underlying lymphoproliferative disorder.

Both criteria must be met:

Serum monoclonal protein ( $\operatorname{IgG}$ or $\operatorname{IgA}) \geq 3 \mathrm{~g} / \mathrm{dL}$ and/or clonal bone marrow plasma cells $\geq 10 \%$ and

Absence of end-organ damage such as lytic bone lesions, anemia, hypercalcemia, or renal failure that can be attributed to a plasma-cell proliferative disorder

Multiple myeloma

All three criteria must be met except as noted:

Clonal bone marrow plasma cells $\geq 10 \%$ or biopsy proven plasmacytoma

Presence of serum and/or urinary monoclonal protein (except in patients with true nonsecretory multiple myeloma) and

Evidence of end organ damage that can be attributed to the underlying plasmacell proliferative disorder, specifically

Hypercalcemia: serum calcium $\geq 11.5 \mathrm{mg} / \mathrm{dL}$ or

Renal insufficiency: serum creatinine $>1.73 \mathrm{mmol} / \mathrm{L}$ ( or $>2 \mathrm{mg} / \mathrm{dL}$ ) or estimated creatinine clearance less than $40 \mathrm{~mL} / \mathrm{min}$

Anemia: normochromic, normocytic with a hemoglobin value of $>2 \mathrm{~g} / \mathrm{dL}$ below the lower limit of normal or a hemoglobin value $<10 \mathrm{~g} / \mathrm{dL}$

Bone lesions: lytic lesions, severe osteopenia, or pathologic fractures

All three criteria must be met:

IgM monoclonal gammopathy of
undetermined significance (IgM MGUS)

Serum $\operatorname{IgM}$ monoclonal protein $<3 \mathrm{~g} / \mathrm{dL}$

Bone marrow lymphoplasmacytic infiltration $<10 \%$, and

No evidence of anemia, constitutional symptoms, hyperviscosity, lymphadenopathy, or hepatosplenomegaly that can be attributed to the underlying lymphoproliferative disorder.

Both criteria must be met:

macroglobulinemia (also referred to as indolent or asymptomatic Waldenström's macroglobulinemia)

Serum IgM monoclonal protein $\geq 3 \mathrm{~g} / \mathrm{dL}$ and/or bone marrow lymphoplasmacytic infiltration $\geq 10 \%$ and

No evidence of anemia, constitutional symptoms, hyperviscosity, lymphadenopathy, or hepatosplenomegaly that can be attributed to the underlying lymphoproliferative disorder.

All criteria must be met:

IgM monoclonal gammopathy (regardless of the size of the M protein) and

$\geq 10 \%$ bone marrow lymphoplasmacytic infiltration (usually intertrabecular) by small lymphocytes that exhibit plasmacytoid or plasma cell differentiation and a typical immunophenotype (e.g., surface IgM+, CD5 ะ, CD10- CD19+, CD20+, and CD23-) that satisfactorily excludes other CD10 lymphoproliferative disorders including chronic lymphocytic leukemia and mantle cell lymphoma

Evidence of anemia, constitutional symptoms, hyperviscosity, lymphadenopathy, or hepatosplenomegaly that can be attributed to the underlying lymphoproliferative disorder. 


\begin{tabular}{|c|c|c|}
\hline Disorder & Disease definition & References \\
\hline \multirow[t]{4}{*}{ Light Chain MGUS } & All criteria must be met: & {$[21]$} \\
\hline & Abnormal FLC ratio $(<0.26$ or $>1.65)$ & \\
\hline & $\begin{array}{l}\text { Increased level of the appropriate involved light chain (increased kappa FLC in } \\
\text { patients with ratio }>1.65 \text { and increased lambda FLC in patients with ratio }< \\
0.26 \text { ) }\end{array}$ & \\
\hline & $\begin{array}{l}\text { No immunoglobulin heavy chain expression on immunofixation and no end- } \\
\text { organ damage attributable to the underlying plasma cell disorder }\end{array}$ & \\
\hline \multirow[t]{5}{*}{ Solitary plasmacytoma } & All four criteria must be met: & {$[22,23]$} \\
\hline & $\begin{array}{l}\text { Biopsy proven solitary lesion of bone or soft tissue with evidence of clonal } \\
\text { plasma cells }\end{array}$ & \\
\hline & Normal bone marrow with no evidence of clonal plasma cells & \\
\hline & $\begin{array}{l}\text { Normal skeletal survey and MRI of spine and pelvis (except for the primary } \\
\text { solitary lesion) }\end{array}$ & \\
\hline & $\begin{array}{l}\text { Absence of end-organ damage such as hypercalcemia, renal insufficiency, } \\
\text { anemia, or bone lesions (CRAB) that can be attributed to a lympho-plasma-cell } \\
\text { proliferative disorder. }\end{array}$ & \\
\hline \multirow[t]{6}{*}{ Systemical amyloidosis } & All four criteria must be met: & {$[24]$} \\
\hline & $\begin{array}{l}\text { Presence of an amyloid-related systemic syndrome (such as renal, liver, heart, } \\
\text { gastrointestinal tract, or peripheral nerve involvement) }\end{array}$ & \\
\hline & $\begin{array}{l}\text { Positive amyloid staining by Congo red in any tissue (e.g., fat aspirate, bone } \\
\text { marrow, or organ biopsy) }\end{array}$ & \\
\hline & $\begin{array}{l}\text { Evidence that amyloid is light-chain related established by direct examination of } \\
\text { the amyloid [possibly using mass spectrometry-based proteomic analysis, or } \\
\text { immuno-electronmicroscopy; note that immunohistochemistry results to type } \\
\text { amyloid may be unreliable] and }\end{array}$ & \\
\hline & $\begin{array}{l}\text { Evidence of a monoclonal plasma-cell proliferative disorder (serum or urine M } \\
\text { protein, abnormal FLC ratio, or clonal plasma cells in the bone marrow). }\end{array}$ & \\
\hline & $\begin{array}{l}\text { Note: Approximately } 2-3 \% \text { of patients with AL amyloidosis will not meet the } \\
\text { requirement for evidence of a monoclonal plasma cell disorder listed above; the } \\
\text { diagnosis of AL amyloidosis must be made with caution in these patients. }\end{array}$ & \\
\hline \multirow[t]{15}{*}{ POEMS syndrome } & All four criteria must be met: & {$[25,26]$} \\
\hline & Polyneuropathy & \\
\hline & Monoclonal plasma-cell proliferative disorder (almost always lambda) & \\
\hline & Any one of the following three other major criteria: & \\
\hline & Sclerotic bone lesions & \\
\hline & Castleman's disease & \\
\hline & Elevated levels of vascular endothelial growth factor $(\mathrm{VEGF})^{\mathrm{a}}$ & \\
\hline & Any one of the following six minor criteria & \\
\hline & Organomegaly (splenomegaly, hepatomegaly, or lymphadenopathy) & \\
\hline & Extravascular volume overload (edema, pleural effusion, or ascites) & \\
\hline & $\begin{array}{l}\text { Endocrinopathy (adrenal, thyroid, pituitary, gonadal, parathyroid, and } \\
\text { pancreatic) }^{\mathrm{b}}\end{array}$ & \\
\hline & $\begin{array}{l}\text { Skin changes (hyperpigmentation, hypertrichosis, glomeruloid hemangiomata, } \\
\text { plethora, acrocyanosis, flushing, and white nails) }\end{array}$ & \\
\hline & Papilledema & \\
\hline & Thrombocytosis/polycythemia & \\
\hline & $\begin{array}{l}\text { Note: Not every patient meeting the above criteria will have POEMS syndrome; } \\
\text { the features should have a temporal relationship to each other and no other } \\
\text { attributable cause. Anemia and/or thrombocytopenia are distinctively unusual in } \\
\text { this syndrome unless Castleman disease is present. }\end{array}$ & \\
\hline
\end{tabular}




\begin{tabular}{ll}
\hline Disorder & Disease definition \\
\hline & References \\
& VEGF level as a major criterion. We suggest that VEGF measured in the serum \\
& or plasma should be at least 3-4-fold higher than the normal reference range for \\
the laboratory that is doing the testing to be considered a major criteria. & \\
& bTo consider endocrinopathy as a minor criterion, an endocrine disorder other \\
than diabetes or hypothyroidism is required, because these two disorders are & common in the general population \\
\hline
\end{tabular}

Modified from Kyle RA, Rajkumar SV. Leukemia 2009;23:3-9. 


\section{TABLE II}

\section{Risk-Stratification of Myeloma}

\begin{tabular}{l}
\hline Standard-risk \\
Hyperdiploidy \\
$\mathrm{t}(11 ; 14)$ \\
$\mathrm{t}(6 ; 14)$ \\
Intermediate-risk \\
$\mathrm{t}(4 ; 14)$ \\
Deletion 13 or hypodiploidy by conventional karyotyping \\
High-risk \\
$17 \mathrm{p}$ deletion \\
$\mathrm{t}(14 ; 16)$ \\
$\mathrm{t}(14 ; 20)$ \\
High-risk gene expression profiling signature \\
\hline
\end{tabular}




\section{TABLE III}

\section{Major Treatment Regimens in Multiple Myeloma}

\begin{tabular}{|c|c|}
\hline Regimen & Usual dosing schedule ${ }^{a}$ \\
\hline \multirow[t]{3}{*}{ Melphalan-prednisone (7-day schedule) [52] } & Melphalan $8-10 \mathrm{mg}$ oral days $1-7$ \\
\hline & Prednisone $60 \mathrm{mg} /$ day oral days $1-7$ \\
\hline & Repeated every 6 weeks \\
\hline \multirow[t]{3}{*}{ Thalidomide-dexamethasone $b_{[53,54]}$} & Thalidomide $200 \mathrm{mg}$ oral days $1-28$ \\
\hline & Dexamethasone $40 \mathrm{mg}$ oral days $1,8,15$, and 22 \\
\hline & Repeated every 4 weeks \\
\hline \multirow[t]{3}{*}{ Lenalidomide-dexamethasone [55] } & Lenalidomide $25 \mathrm{mg}$ oral days $1-21$ every 28 days \\
\hline & Dexamethasone $40 \mathrm{mg}$ oral days $1,8,15$, and 22 every 28 days \\
\hline & Repeated every 4 weeks \\
\hline \multirow[t]{3}{*}{ Bortezomib-Dex $b_{[56]}$} & Bortezomib $1.3 \mathrm{mg} / \mathrm{m}^{2}$ subcutaneous or intravenous days $1,8,15$, and 22 \\
\hline & $\begin{array}{l}\text { Dexamethasone } 20 \mathrm{mg} \text { oral on day of and day after bortezomib (or } 40 \mathrm{mg} \\
\text { days } 1,8,15 \text {, and } 22 \text { ) }\end{array}$ \\
\hline & Repeated every 4 weeks \\
\hline \multirow[t]{4}{*}{ Melphalan-prednisone-thalidomide $[57,58]$} & $\begin{array}{l}\text { Melphalan } 0.25 \mathrm{mg} / \mathrm{kg} \text { oral days } 1-4 \text { (use } 0.20 \mathrm{mg} / \mathrm{kg} / \mathrm{day} \text { oral days } 1-4 \text { in } \\
\text { patients over the age of } 75 \text { ) }\end{array}$ \\
\hline & Prednisone $2 \mathrm{mg} / \mathrm{kg}$ oral days $1-4$ \\
\hline & Thalidomide $100-200 \mathrm{mg}$ oral days $1-28$ (use $100 \mathrm{mg}$ dose in patients $>75$ ) \\
\hline & Repeated every 6 weeks \\
\hline \multirow[t]{4}{*}{ Bortezomib-melphalan-prednisone- $b_{[59-61]}$} & Bortezomib $1.3 \mathrm{mg} / \mathrm{m}^{2}$ subcutaneous or intravenous days $1,8,15$, and 22 \\
\hline & Melphalan $9 \mathrm{mg} / \mathrm{m}^{2}$ oral days $1-4$ \\
\hline & Prednisone $60 \mathrm{mg} / \mathrm{m}^{2}$ oral days $1-4$ \\
\hline & Repeated every 35 days \\
\hline \multirow[t]{4}{*}{ Bortezomib-thalidomide-dexamethasone $b_{[62]}$} & Bortezomib $1.3 \mathrm{mg} / \mathrm{m}^{2}$ subcutaneous or intravenous days $1,8,15$, and 22 \\
\hline & Thalidomide $100-200 \mathrm{mg}$ oral days $1-21$ \\
\hline & $\begin{array}{l}\text { Dexamethasone } 20 \mathrm{mg} \text { oral on day of and day after bortezomib (or } 40 \mathrm{mg} \\
\text { days } 1,8,15 \text {, and } 22 \text { ) }\end{array}$ \\
\hline & Repeated every 4 weeks $\times 4$ cycles as pretransplant induction therapy \\
\hline \multirow[t]{4}{*}{ Bortezomib-cyclophosphamide-dexamethasone $b_{(\mathrm{VCD})}[63,64]$} & Cyclophosphamide $300 \mathrm{mg} / \mathrm{m}^{2}$ orally on days $1,8,15$, and 22 \\
\hline & $\begin{array}{l}\text { Bortezomib } 1.3 \mathrm{mg} / \mathrm{m}^{2} \text { subcutaneous or intravenously on days } 1,8,15 \text {, and } \\
22\end{array}$ \\
\hline & Dexamethasone $40 \mathrm{mg}$ orally on days on days $1,8,15$, and 22 \\
\hline & Repeated every 4 weeks $c$ \\
\hline \multirow[t]{4}{*}{ Bortezomib-lenalidomide-dexamethasone ${ }[65-67]$} & Bortezomib $1.3 \mathrm{mg} / \mathrm{m}^{2}$ subcutaneous or intravenous days 1,8 , and 15 \\
\hline & Lenalidomide $25 \mathrm{mg}$ oral days $1-14$ \\
\hline & $\begin{array}{l}\text { Dexamethasone } 20 \mathrm{mg} \text { oral on day of and day after bortezomib (or } 40 \mathrm{mg} \\
\text { days } 1,8,15 \text {, and } 22 \text { ) }\end{array}$ \\
\hline & Repeated every 3 weeks $d$ \\
\hline
\end{tabular}


${ }^{c}$ Omit day 22 dose if counts are low or when the regimen is used as maintenance therapy; when used as maintenance therapy for high risk patients, delays can be instituted between cycles.

$d_{\text {Omit day }} 15$ dose if counts are low or when the regimen is used as maintenance therapy; when used as maintenance therapy for high risk patients, lenalidomide dose may be decreased to $10-15 \mathrm{mg}$ per day, and delays can be instituted between cycles as done in total therapy protocols $[68,69]$. 


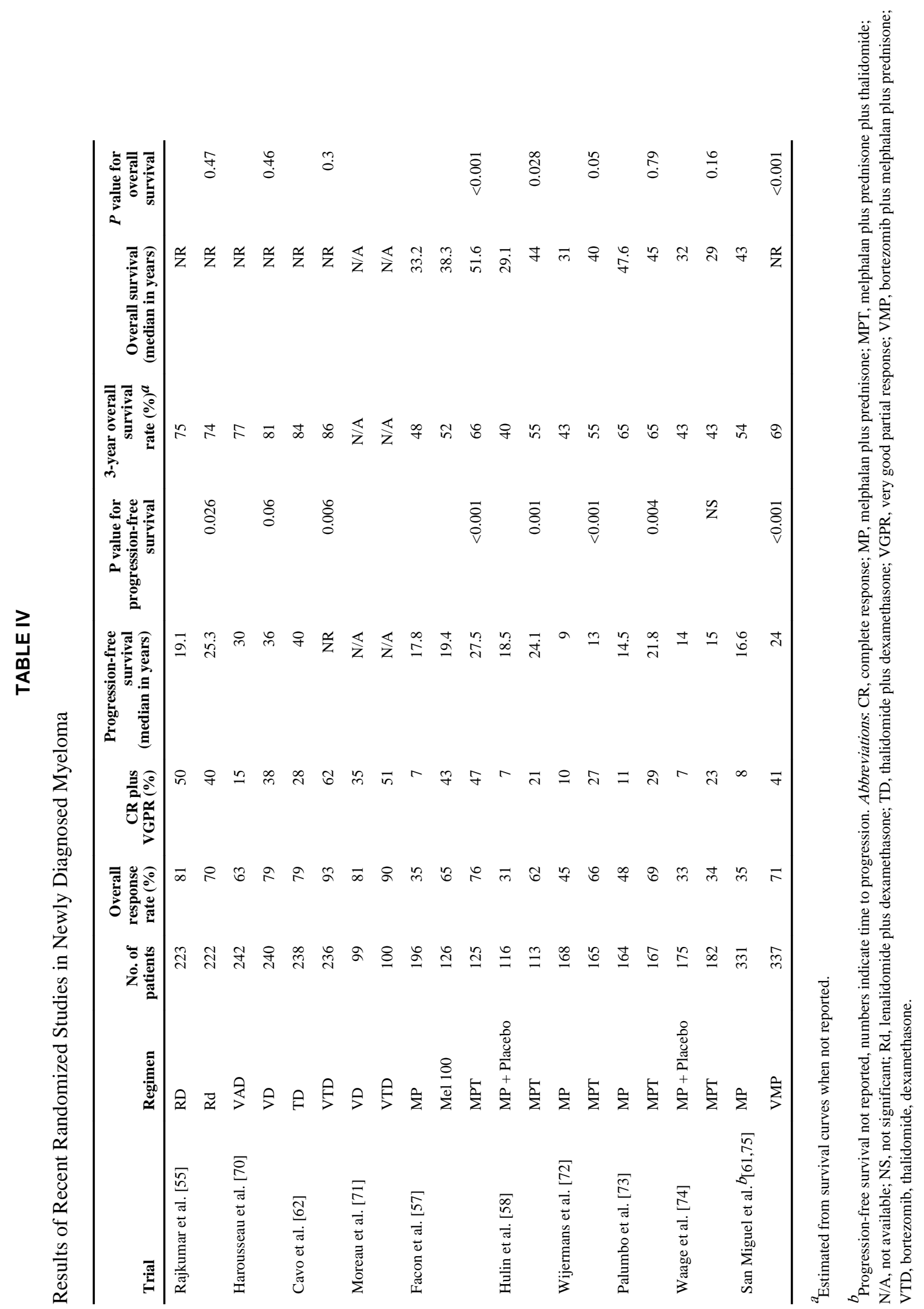

